\title{
PENGARUH CAMPURAN KAPUR DAN ABU JERAMI GUNA MENINGKATKAN KUAT GESER TANAH LEMPUNG
}

\author{
Abdul Jalil $^{1)}$, Hamzani ${ }^{2}$, Nadia Mulyanah ${ }^{3)}$ \\ Jurusan Teknik Sipil Universitas Malikussaleh \\ email:nadia_mulyanah@yahoo.com
}

\begin{abstract}
Abstrak
Lempung adalah terdiri dari butiran-butiran sangat kecil dan menunjukkan sifat plastisitas dan kohesif. Pada penelitian ini digunakan kapur dan abu jerami untuk perbaikan tanah lempung di desa Cot Girek Kandang yang berdaya dukung rendah. Tujuan penelitian ini adalah untuk mengetahui nilai kuat geser dengan campuran 5\% kapur dan variasi abu jerami 2\%, 4\% dan 6\%. Tanah di desa Cot Girek Kandang termasuk tanah lempung berpasir. Pada variasi campuran 5\% kapur $+2 \%$ AJP didapat kadar air optimum 17,5\% dengan kerapatan kering tertinggi $1,65 \mathrm{gr} / \mathrm{cm}^{3}$. Uji triaxial nilai sudut geser dalam tanah tertinggi didapat pada persentase penambahan $5 \%$ kapur $+2 \%$ AJP. Nilai kohesi tertinggi pada persentase penambahan 5\% kapur $+4 \%$ AJP. Uji direct shear nilai sudut geser dalam tanah tertinggi didapat pada persentase penambahan 5\% kapur $+6 \%$ AJP. Nilai kohesi tertinggi didapat pada persentase penambahan $5 \%$ kapur $+2 \%$ AJP. Maka dari itu campuran kapur dan abu jerami padi dapat dipakai karena dapat meningkatkan nilai kuat geser.
\end{abstract}

Kata kunci : Kapur, Abu jerami padi, Kuat geser.

\section{Pendahuluan}

Lereng merupakan suatu kondisi permukaan tanah dimana terdapat perbedaan elevasi antara satu daerah dengan daerah yang lain dan membentuk kemiringan tertentu. Kelongsoran tanah merupakan proses perpindahan massa tanah secara alami dari tempat yang tinggi ke tempat yang lebih rendah.

Pergerakan tanah ini terjadi karena perubahan keseimbangan daya dukung tanah, dan akan berhenti setelah mencapai keseimbangan yang baru. Seperti tanah lereng yang ada di desa Cot Girek Kecamatan Muara Dua. Tanah pada lokasi tersebut merupakan tanah yang sering runtuh pada saat musim hujan dan perlu dilakukan perbaikan tanah sebelum dibangun bangunan.

Adapun usaha-usaha untuk memperbaiki sifat fisis dan sifat mekanis tanah telah banyak dilakukan dengan cara fisis, mekanis dan kimiawi. Cara fisis dilakukan dengan mencampurkan tanah lempung dengan tanah bergradasi atau menambah serat fiber, cara mekanis yaitu memberi perkuatan bahan sintetis yang terbuat dari bahan polimerisasi minyak bumi pada tanah dan cara kimiawi dengan menambah semen, kapur, abu terbang dan abu sekam padi serta bahan kimia lainnya.Pada penelitian ini, dicoba untuk melakukan perkuatan terhadap tanah lereng tersebut dengan melakukan pencampuran kapur dan abu jerami untuk menstabilisasi tanah lereng. 


\section{Tinjauan Kepustakaan}

\subsection{Triaxial test}

Triaxial test merupakan salah satu percobaan menentukan besarnya kohesi dan sudut geser dari suatu contoh tanah dan percobaannya menggunakan alat triaxial UU test. Triaxial UU test (Unconsolidated Undrained) ialah percobaan triaxial dimana tidak terjadi konsolidasi dan diberi tegangan geser dan jalannya air tertutup, untuk mengetahui besarnya kohesi dan sudut geser dalam tanah dilakukan dengan bantuan lingkaran Mohr.Karena kekuatan geser kondisi air termampatkan dari tanah tidak tergantung pada tegangan penyekap, maka persamaan kuat geser dapat dinyatakan dalam persamaan sebagai berikut

$$
\tau_{f}=\frac{\sigma_{1}}{2}=\frac{q_{u}}{2}=C_{u}
$$

\subsection{Direct shear test}

Kekuatan geser tanah (soil shear strength) dapat didefinisikan sebagai kemampuan maksimum tanah untuk bertahan terhadap usaha perubahan bentuk pada kondisi tekanan (pressure) dan kelembaban tertentu.

Menurut Dun et.al (1980) mengatakan bahwa jika kekuatan tanah lebih besar daripada tegangan yang bekerja pada tanah maka tanah aman terhadap keruntuhan pada bidang yang ditinjau, tetapi jika tegangan tersebut lebih besar daripada kekuatan tanah maka akan terjadi keruntuhan

Selama pengujian kuat geser langsung dicatat harga regangan dan nilai dial. Kedua nilai tersebut digunakan dalam perhitungan dengan memakai persamaan sebagai berikut:

$$
\begin{aligned}
& \text { Beban }=\text { dial } x \text { Kalibrasi Alat } \\
& \text { Tegangan Geser...... }=\frac{\text { Beban }}{\text { Luas Penampang }}
\end{aligned}
$$

\subsection{Dayadukungtanah}

Menurut Craig, R.F daya dukung tanah merupakan pendukung pondasi, dimana suatu pondasi merupakan bagian dari struktur yang menyalurkan beban langsung kelapisan tanah di bawahnya. Dengan demikian pondasi-pondasi harus memenuhi dua persyaratan dasar yaitu:

1. Faktor keamanan terhadap keruntuhan geser dari tanah pendukung harus memadai, biasanya 2,5 sampai 3 .

2. Penurunan pondasi dapat terjadi dalam batas toleransi dan penurunan sebagai (differential settlement) tidak boleh menyebabkan kerusakan serius atau mempengaruhi fungsi struktur.

Daya dukung tanah izin $\left(\mathrm{q}_{\mathrm{a}}\right)$ didefinisikan sebagai tekanan maksimum yang boleh dikerjakan pada tanah sedemikian rupa sehingga kedua kebutuhan dasar di atas terpenuhi.

Pengaruh Campuran Kapur Dan Abu Jerami Guna Meningkatkan Kuat Geser Tanah Lempung - Abdul Jalil, Hamzani, Nadia Mulyanah 


\subsection{Material Pada Pengujian}

\subsubsection{Tanah Lempung}

Menurut Wesley, L.D (1977), tanah lempung terdiri dari butir-butir yang sangat kecil dan menunjukkan sifat plastisitas dan kohesi. Kohesi menunjukkan kenyataan bahwa bagian-bagian itu melekat satu sama lainnya, sedangkan plastisitas adalah sifat yang memungkinkan bentuk bahan itu berubah-ubah tanpa perubahan isi atau tanpa kembali ke bentuk aslinya, dan tanpa terjadi retakanretakan atau terpecah-pecah.

Kapur dolomite, Dolomit dipilih untuk konstruksi dan aplikasi produk bangunan yang disebabkan karena kekerasannya meningkat dan kepadatan. Gambar kapur Dolomit seperti diperlihatkan pada Gambar 1

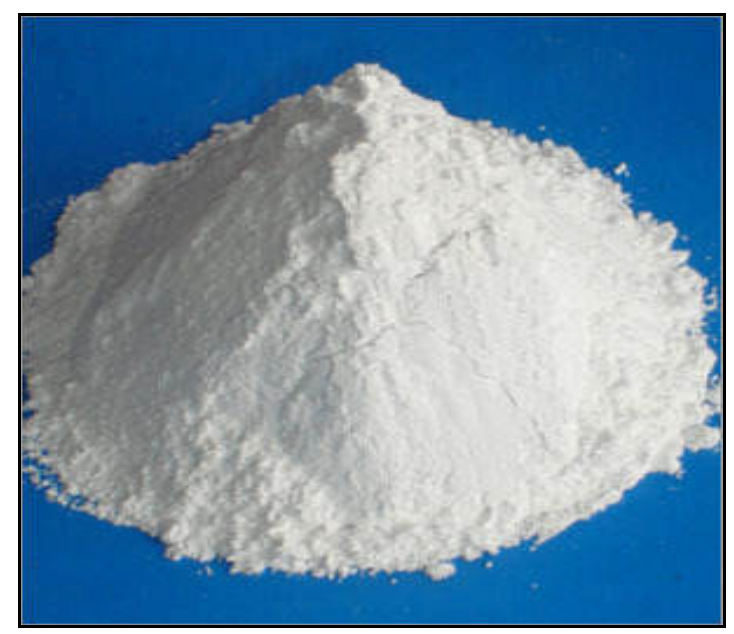

Gambar 1 Kapur Dolomit

Abu jerami padi, Jerami yang akan digunakan dalam stabilisasi ini adalah abu hasil dari pembakaran jerami yang kemudian disaring lolos saringan no 200 seperti diperlihatkan pada Gambar 2

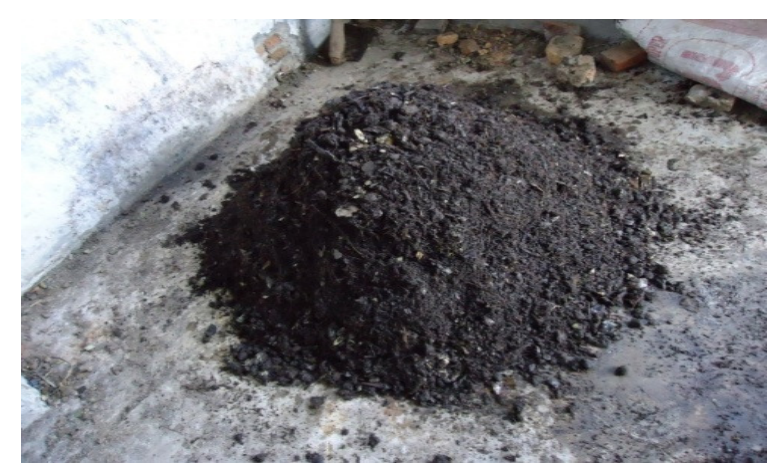

Gambar 2 Abu Jerami Padi

Pengaruh Campuran Kapur Dan Abu Jerami Guna Meningkatkan Kuat Geser Tanah Lempung - Abdul Jalil, Hamzani, Nadia Mulyanah 


\section{Metode Penelitian}

Penelitian ini merupakan campuran kapur dan abu jerami pada tanah lempung terhadap nilai kuat geser tanah. Tanah desa cot girek Kandang di uji Properties dan uji Mekanik. Uji mekanik terdiri atas uji Pemadatan, Direct shear dan Triaksial. Material aditif (Kapur Dolomit) diperoleh dari Toko Bahan Bangunan di Kota Lhokseumawe dan abu sabut kelapadi Krueng Mane. Material aditif ini di uji gradasi dengan lolos saringan No. 200.

Tabel 1 Jumlah Benda Uji Untuk Triaxial

\begin{tabular}{|l|l|c|}
\hline No & JenisPengujian & Jumlah Benda Uji \\
\hline 1 & Tanah Asli (Tanah Lempung 100\%) & 3 buah \\
\hline 2 & Tanah $+5 \%$ kapur $+2 \%$ jerami & 3 buah \\
\hline 3 & Tanah $+5 \%$ kapur $+4 \%$ jerami & 3 buah \\
\hline 4 & Tanah $+5 \%$ kapur $+6 \%$ jerami & 3 buah \\
\hline \multicolumn{2}{|c|}{ Jumlah Benda Uji } & 12 buah \\
\hline
\end{tabular}

\section{Hasil dan Pembahasan}

\subsection{Hasil}

\subsubsection{Pemeriksaan Sifat Fisis Tanah (Properties Tanah)}

Kadar air tanah (w) 14,48\%, Spesifik Gravity (Gs) 2,65, bahwa tanah tersebut dikatagorikan kepada tanah lempung organik karena nilai berat jenis tanah lempung organik berkisar antara 2,58-2,65. Berat volume tanah basah yaitu $1,83 \mathrm{gram} / \mathrm{cm}^{3}$ dan berat volume tanah kering yaitu $1,60 \mathrm{gram} / \mathrm{cm}^{3}$.

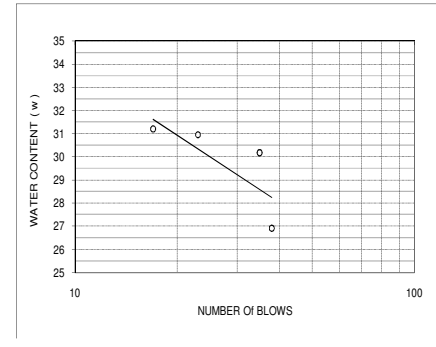

\section{Gambar 3 grafik pengujian batas cair tanah asli}

Pada Gambar 3 dapat dijelaskan bahwa nilai batas cair untuk tanah asli adalah $30 \%$. Selanjutnya dilakukan pengujian batas plastis diperoleh $24,8 \%$, dengan demikian nilai $P I$ dapat $P I=L L-P L$, maka didapat nilai $P I$ adalah 5,2 \%. Selanjutnya dapat diketahui klasifikasi tanah dengan metode USCS dengan menggunakan Gambar 4. 


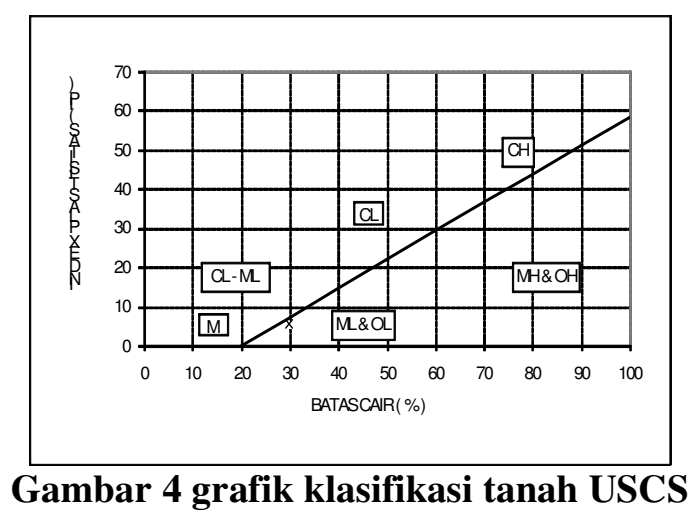

Klasifikasi tanah menurut USCS, tanah tersebut termasuk ke dalam golongan ML dan OL yaitu lanau tak organik dan pasir sangat halus, serbuk batuan atau pasir halus berlanau dan berlempung dengan plastisitas rendah.

\subsubsection{Pemeriksaan Sifat Mekanik Tanah}

Pengujian mekanik terdiri atas uji Pemadatan (proctor test) dilakukan pada tanah asli yang dipadatkan pada keadaan kadar air optimum sehingga tercapai keadaan paling padat.

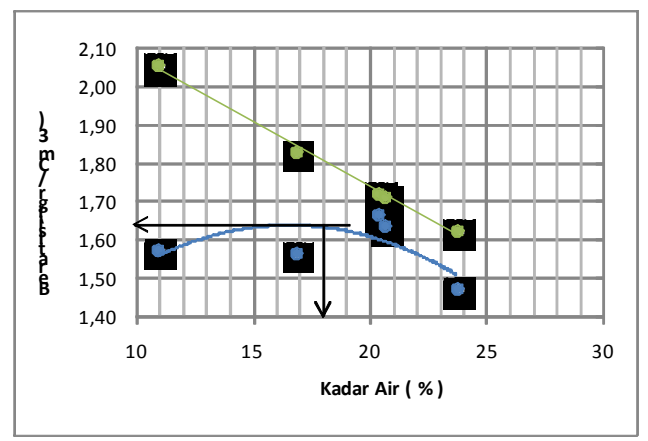

\section{Gambar 5 Grafik pemadatan tanah}

Pada kurva diatas Gambar 5 Nilai kadar air optimum $\left(W_{\text {opt }}\right)$ dan berat isi kering $\left(\gamma_{d}\right)$ sebesar tanah asli yang didapatkan $\left(W_{\text {opt }}=18 \%\right.$, dan $\left.\gamma_{d}=1,63 \mathrm{gr} / \mathrm{cm}^{3}\right)$.

\subsubsection{Pengujian Triaksial}

Selanjutnya pada uji triaksial diperoleh nilai sudut geser (C) dan nilai kohesi tanah (C) seperti pada Gambar 6.

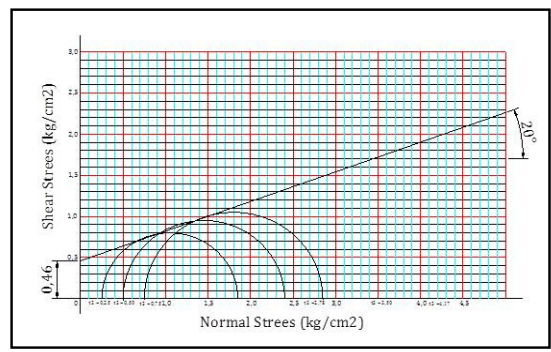

Gambar 6 Grafik Lingkaran Mohr tanah asli

Pengaruh Campuran Kapur Dan Abu Jerami Guna Meningkatkan Kuat Geser Tanah Lempung - Abdul Jalil, Hamzani, Nadia Mulyanah 
Dengan menarik garik singgung pada semua lingkaran mohr diatas maka didapat sudut geser $(\square)$ sebesar $20^{\circ}$ dan kohesi (C) sebesar $0,46 \mathrm{~kg} / \mathrm{cm}^{2}$.

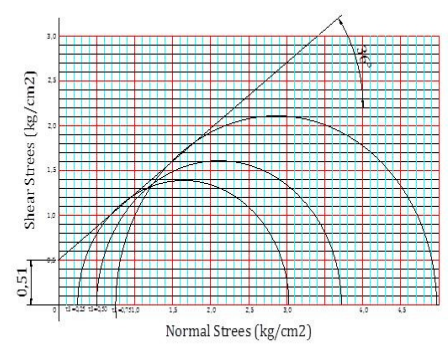

\section{Gambar 7 Grafik Lingkaran Mohr Pada Variasi Campuran 5\% Kapur + 2\% AJP}

Pada penambahan $5 \%$ kapur dan $2 \%$ Abu Jerami Dengan menarik garik singgung pada semua lingkaran mohr diatas maka didapat sudut geser ( $\$$ ) sebesar $36^{\circ}$ dan kohesi (C) sebesar $0,51 \mathrm{~kg} / \mathrm{cm}^{2}$.

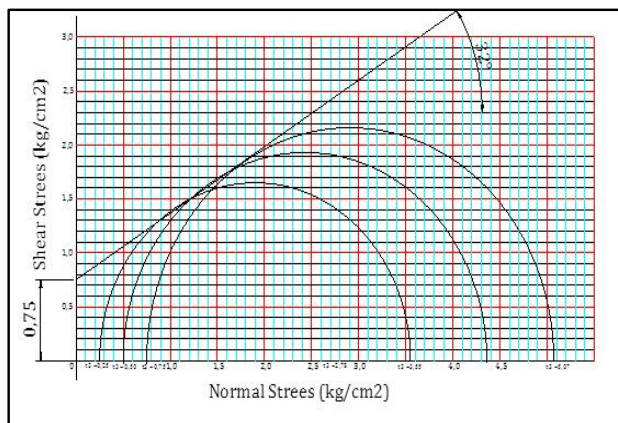

\section{Gambar 8 Grafik Lingkaran Mohr Pada Variasi Campuran 5\% Kapur + 4\% AJP}

Dengan menarik garik singgung pada semua lingkaran mohr diatas maka didapat sudut geser ( $\phi$ ) sebesar $32^{\circ}$ dan kohesi (C) sebesar $0,75 \mathrm{~kg} / \mathrm{cm}^{2}$.

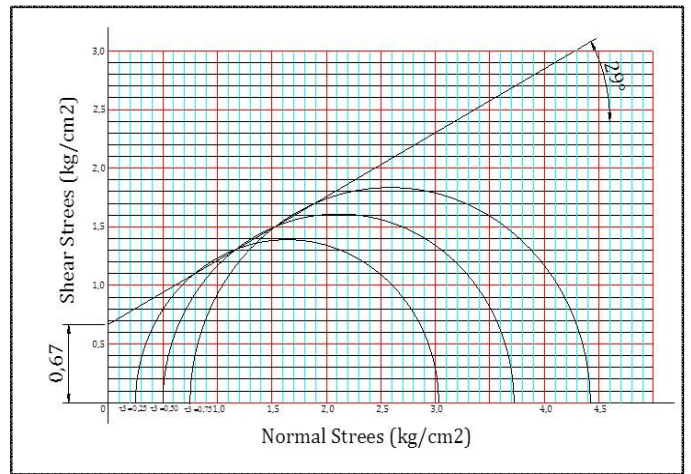

\section{Gambar 9 Grafik Lingkaran Mohr Pada Variasi Campuran 5\% Kapur + 6\% AJP}


Dengan menarik garik singgung pada semua lingkaran mohr diatas maka didapat sudut geser ( $\phi)$ sebesar $29^{\circ}$ dan kohesi (C) sebesar $0,67 \mathrm{~kg} / \mathrm{cm}^{2}$.

\subsubsection{Pengujian direct shear}

Pada pengujian direct shear terhadap tanah $+0 \%$ kapur $+0 \%$ AJP, tanah + $5 \%$ Kapur $+2 \%$ AJP, tanah $+5 \%$ Kapur $+4 \%$ AJP, dan tanah $+5 \%$ Kapur $+6 \%$ AJP kadar air yang dipakai untuk pengujian ini diperoleh dari kadar air optimum (Wopt) yang didapat dari hasil pengujian proctor test. Dengan benda uji 3 sampel dalam satu variasi, sampel I diberikan beban $=1 \mathrm{~kg}$, sampel II $=2 \mathrm{~kg}$, sampel III = $3 \mathrm{~kg}$. Jadi benda uji keseluruhannya dalam pengujian direct shear ada 12 sampel benda uji. Uji direct shear dilakukan di Laboratorium Mekanika Tanah Teknik Sipil, Universitas Malikussaleh. Hasil dari Direct Shear tersebut diperlihatkan pada Tabel 2.

Tabel 2 Hasil pengujian direct shear

\begin{tabular}{|c|c|c|c|}
\hline No & Campuran & $\phi\left(^{\circ}\right)$ & $\begin{array}{c}\mathrm{C} \\
\left(\mathrm{kg} / \mathrm{cm}^{2}\right)\end{array}$ \\
\hline 1 & $\begin{array}{r}\text { Tanah }+ \text { 0\% Kapur }+ \\
0 \% \text { AJP }\end{array}$ & 26,565 & 0,160 \\
\hline 2 & $\begin{array}{r}\text { Tanah + 5\% Kapur }+ \\
2 \% \text { AJP }\end{array}$ & 15,642 & 0,46 \\
\hline 3 & $\begin{array}{r}\text { Tanah + 5\% Kapur }+ \\
4 \% \text { AJP }\end{array}$ & 16,70 & 0,31 \\
\hline 4 & $\begin{array}{r}\text { Tanah + 5\% Kapur }+ \\
6 \% \text { AJP }\end{array}$ & 39,805 & 0,143 \\
\hline
\end{tabular}

\subsection{Pembahasan}

\subsubsection{Sifat-sifat fisis}

Kegunaan batas atterberg dalam perencanaan adalah memberikan gambaran secara garis besar akan sifat-sifat tanah yang bersangkutan. Bilamana kadar airnya sangat tinggi, campuran tanah dan air akan menjadi sangat lembek. Tanah yang batas cairnya tinggi biasanya mempunyai sifat teknik yang buruk yaitu kekuatannya rendah, sedangkan compressibilitasnya tinggi sehingga sulit dalam hal pemadatan. Hasil yang didapat dari pengujian batas atterberg didapat nilai IP $5,20 \%$.

\subsubsection{Sifat-sifat mekanis}

Pemadatan (Compaction), dari hasil yang diperoleh bahwa penambahan kapur dan abu jerami padi pada tanah lempung dapat meningkatkan nilai kepadatan kering ( $\square$ d). Nilai kerapatan kering ( $\square$ d) paling tinggi didapat pada pencampuran tanah $+5 \%$ kapur $+2 \%$ abu jerami padi. Namun jika semakin banyak persentase abu jerami padi yang ditambahkan maka dapat menurunkan nilai kerapatan kering tanah ( $\square$ d). Menurunnya nilai kerapatan kering tanah disebabkan karena abu jerami padi mengandung silica yang jika terlalu banyak dicampurkan dengan air akan menjadi encer sehingga sulit untuk dipadatkan. 
Triaxial, dari hasil pengujian triaxial, nilai sudut geser dalam ( $\square$ ) paling maksimal didapat pada persentase penambahan 5\% kapur $+2 \%$ abu jerami padi. Semakin banyak persentase penambahan abu jerami padi nilai sudut geser dalam ( $\square$ ) mengalami penurunan. Untuk nilai kohesi maksimal (C) pada uji triaxial didapat pada persentase penambahan $5 \%$ kapur $+4 \%$ abu jerami padi. Meningkatnya nilai sudut geser dalam dan nilai kohesi ini disebabkan oleh kandungan silica yang terdapat pada kapur dan abu jerami padi yang saling mengikat. Namun kenaikan nilai sudut geser dalam tanah dan nilai kohesi tanah dikontrol oleh jumlah penambahan abu jerami padi. Hal ini diperlihatkan pada Gambar 10 dan Gambar 11.

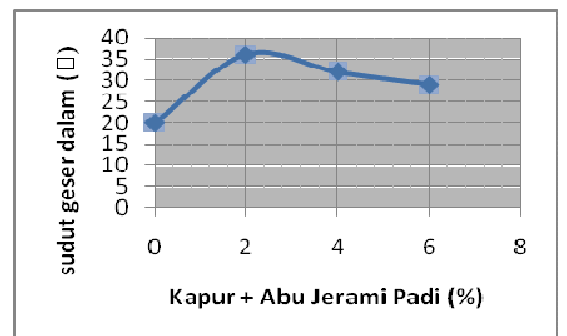

\section{Gambar 10 Grafik hubungan antara persentase Kapur + AJP dengan nilai sudut geser dalam pada uji Triaxial}

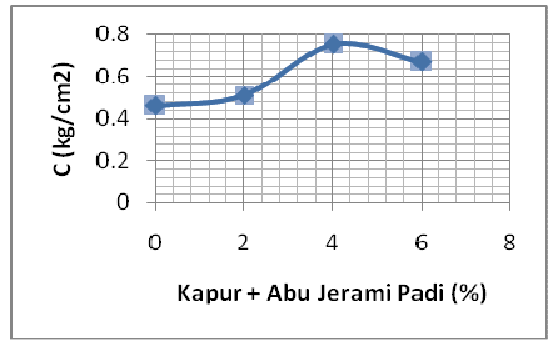

\section{Gambar 11 Grafik hubungan antara persentase Kapur + AJP dengan nilai Kohesi tanah $(C)$ pada uji Triaxial}

Direct Shear, dari hasil pengujian direct shear, nilai sudut geser dalam ( $\square$ ) maksimal didapat pada persentase penambahan 5\% kapur $+6 \%$ abu jerami padi. Sedangkan untuk nilai kohesi (C) maksimal didapat pada persentase penambahan $5 \%$ kapur $+2 \%$ abu jerami padi. Meningkat dan menurunnya nilai sudut geser dalam tanah dan nilai kohesi ini juga dipengaruhi oleh jumlah persentase penambahan kapur dan abu jerami padi. Hal ini diperlihatkan pada Gambar 12 dan Gambar 13.

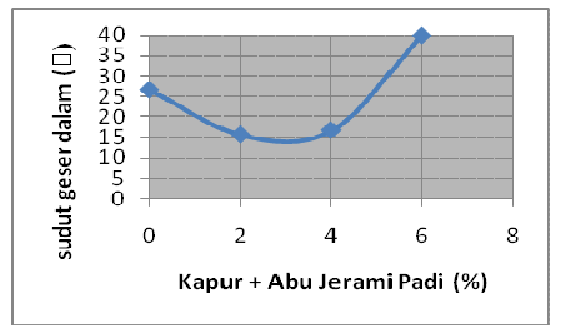

Gambar 12 Grafik hubungan antara persentase Kapur + AJP dengan nilai sudut geser dalam pada uji Direct Shear 


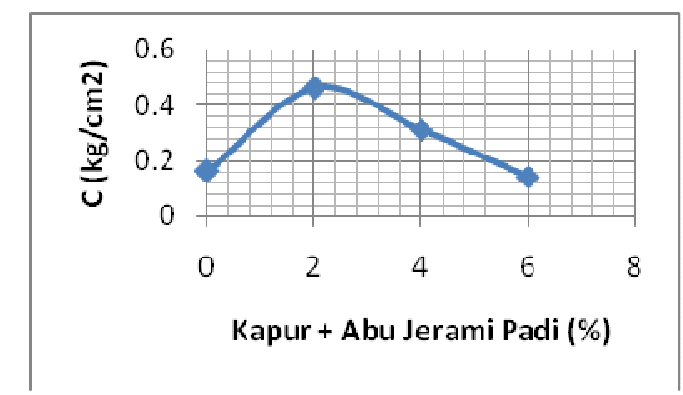

\section{Gambar 13 Grafik hubungan antara persentase Kapur + AJP dengan nilai Kohesi tanah $(C)$ pada uji Direct Shear}

\section{Kesimpulan dan Saran}

\subsection{Kesimpulan}

Dari hasil penelitian dan pembahasan dapat diambil beberapa kesimpulan sebagai berikut:

1. Penambahan abu jerami padi pada tanah lempung dapat meningkatkan nilai kepadatan kering ( $\mathrm{r}$ d). Nilai kerapatan kering ( $\mathrm{r}$ d) paling tinggi didapat pada pencampuran tanah $+5 \%$ kapur $+2 \%$ abu jerami padi, namun jika semakin banyak persentase abu jerami padi yang ditambahkan maka dapat menurunkan nilai kerapatan kering tanah ( $\mathrm{r} d)$.

2. Persentase penambahan $2 \%$ abu jerami padi, semakin banyak persentase penambahan abu jerami padi nilai sudut geser dalam $(\phi)$ mengalami penurunan. Untuk nilai kohesi maksimal (C) pada uji triaxial didapat pada persentase penambahan $+4 \%$ abu jerami padi. Meningkatnya nilai sudut geser dalam dan nilai kohesi ini disebabkan oleh kandungan silica yang terdapat pada kapur dan abu jerami padi yang saling mengikat. Namun kenaikan nilai sudut geser dalam tanah dan nilai kohesi tanah dikontrol oleh jumlah penambahan abu jerami padi.

3. Dari hasil pengujian tiaxial dan direct shear, penambahan kapur dan abu jerami padi dapat meningkat nilai sudut geser dalam dan nilai kohesi tanah lempung.

4. Pada uji triaxial nilai sudut geser tanah maksimal didapat pada persentase penambahan $5 \%$ kapur $+2 \%$ abu jerami padi. Untuk nilai kohesi maksimal didapat pada persentase penambahan $5 \%$ kapur $+4 \%$ abu jerami.

5. Pada uji direct shear nilai sudut geser tanah maksimal didapat pada persentase penambahan $5 \%$ kapur $+6 \%$ abu jerami. Untuk nilai kohesi maksimal didapat pada persentase penambahan $5 \%$ kapur $+2 \%$ abu jerami.

6. Untuk perhitungan pondasi dangkal digunakan hasil perhitungan Triaxial karena hasilnya lebih akurat.

\subsection{Saran}

Untuk melanjutkan penelitian tentang campuran kapur dan abu jerami padi dapat dilakukan penelitian dengan variasi kapur dibawah 5\% dan berbeda variasi penambahan abu jerami padi agar dapat melengkapi hasil penelitian ini sehingga mempertajam informasi tentang penggunaan abu jerami padi. 


\section{Daftar Kepustakaan}

Anonim.ASTM (American Society for Testing and Materials) D2434- 68. 2006. Standard Test Method for Permeability of Granular Soil (Constant Head). United States: IHS di bawah lisensi ASTM.

Bowles, Joseph E. 1993. Sifat-Sifat Fisis Dan Geoteknis Tanah (Mekanika Tanah). EdisiKedua. Terjemahan: Johan K. Hainim. Jakarta: Erlangga.

Craig, R. F. 1987. Mekanika Tanah. EdisiKeempat. Terjemahan: Budi Susilo. S. Jakarta: Erlangga.

Das, Braja M. 1998. Mekanika Tanah (Prinsip- Prinsip Rekayasa Geoteknis), Jilid 1, Terjemahan: Noor Endah dan Indrasurya B. Mochtar. Jakarta: Erlangga.

Das, Braja M. 1993. Mekanika Tanah (Prinsip- Prinsip Rekayasa Geoteknis), Jilid 2.Terjemahan: Noor Endah dan Indrasurya B. Mochtar. Jakarta: Erlangga.

Hardiyatmo, H.C. 1994. Mekanika Tanah 2. Jakarta: PT. Gramedia Pustaka Utama.

Palar, Hariman, dkk. Mei 2013. Pengaruh Pencampuran Tras Dan Kapur Pada Lempung Ekspansif Terhadap Nilai Daya Dukung. Jurnal Sipil Statik Vol.1 No.6, Mei 2013 (390-399) ISSN: 2337-6732.

Setyowati, Anita. Januari 2014. DayaDukung Tanah Lempung yang Distabilisasi dengan Spent Catalyst RCC 15 dan Kapur.Jurnal BENTANG Vol. 2 No.1.

Wesley, L. D., 1977. Mekanika Tanah. BadanPenerbit PU. Jakarta. 